\title{
Immunohistochemical Fiber Type Profile in the Human Vocal Muscle
}

\author{
Perfil Inmunohistoquímico de los Tipos de Fibras en el Músculo Vocal Humano
}

\author{
"María José López; *Michael Zárate; **Mario Cantín; ***Daniela Zavando \& **** Iván Suazo Galdames
}

LÓPEZ, M. J.; ZÁRATE, M.; CANTÍN, M.; ZAVANDO, D. \& SUAZO, G. I. Immunohistochemical fiber type profile in the human vocal muscle. Int. J. Morphol., 29(4):1158-1161, 2011.

SUMMARY: The vocal muscle is a striated muscle with important functions in the emission of laryngeal sound and physiology of the voice. Therefore the knowledge of its constitution is the basis for the prevention and management of voice disorders. We used 10 samples from the middle third of vocal muscles obtained from autopsies of 6 male and 4 female subjects aged between 36 and 71 years. The samples were analyzed with BA-F8 monoclonal antibody to slow type I fibers, and antimyosin HC monoclonal antibody and antimyosin fast clone MY-32 antibody for types IIA, IIB, IIX, and neonatal fibers. We determined the distribution of the muscle fiber types and morphometric characteristics, evaluating the differences by sex and age group. The human vocal muscle presented a heterogeneous formation with a predominance of type II fibers at $51.99 \%$, while type I fibers reached $48.01 \%$; this difference was significant (p <0.05). Comparing fiber subtypes IIA and IIX, there is a slight predominance of type IIX fibers, although this is not statistically significant ( $p>0.05)$. In conclusion, the human vocal muscle the fibers were predominantly type II fast.

KEY WORDS: Voice; Vocal cords; Laryngeal muscles; Myosin Type I; Myosin Type II; Immunohistochemistry.

\section{INTRODUCTION}

The vocal muscle is an intrinsic larynx muscle disposed between the vocal process and the oblong pit of the arytenoid cartilage, and the inner face of the thyroid cartilage near the midline. This muscle is the most important element of the vocal folds due to its role in the shortening and relaxation of these folds. Histologically it is composed of striated skeletal muscle tissue, grouped in bundles that are arranged to determine the upper portions, and lower average muscle (Di Fiore, 2001; Latarjet \& Ruiz Liard, 1997). The altered function of the muscles of the larynx is presented in various diseases of the voice, these changes have expression in the metabolism of muscle fibers in its organization and morphological appearance, as histochemical and immunohistochemical study of muscle fibers is a valuable tool for evaluation. The histochemical differentiation of muscle fibers supports the diagnosis of many myopathies (Hebling \& Esquisatto, 2005). The preferred method for the differentiation of muscle fibers is based on the histochemical reaction for the identification of the enzyme nicotinamide dinucleotides tetrazolium reductase (NADH-
TR) (Dubowitz et al., 1985), which can be classified into Type I (slow, fatigue-resistant); and Type II, subclassified as Type IIa (fast, fatigue-resistant) and Type IIb (fast, fatigable) (López-Chicharro, 2006), in the human vocal muscle a higher frequency of fibers Type I and Type II that characterizes the muscle as having aerobic metabolism, resistance to fatigue, and fast contraction has been reported (Guida \& Zorzetto, 2000). However, the laryngeal muscle exhibits physiological plasticity, being subject to neural and hormonal modulation, therefore the distribution of its fibers may vary at different stages of life (Hoh, 2005; Wu et al., 2000a). The neural regulation allows distinct allotypes in laryngeal muscle fibers and their analysis is very important in the evaluation of laryngeal neuropathy (Rhee et al., 2004; Rhee et al., 2009).

The knowledge of the normal distribution of muscle fiber types of human vocal muscle will have a gold standard as a reference in the diagnosis of vocal muscle pathology and the evaluation of therapeutic interventions or vocal training. However there is insufficient analysis of the

\footnotetext{
* Escuela de Fonoaudiología, Universidad de Talca, Chile.

** Universidad de La Frontera, Chile.

**** Universidad Autónoma de Chile, Chile.

***** Universidad de Talca, Chile.
} 
distribution of muscle fiber types in adult human vocal $(\mathrm{Wu}$ et al., 2000b).

With this background, the objective of this research is to differentiate the human vocal muscle fibers by immunohistochemistry and analyze their share in the vocal muscle of adult subjects.

\section{MATERIAL AND METHOD}

We designed a cross-sectional study based on vocal muscle parts obtained from 10 adult human cadavers, 4 females with a mean age of 52 years (SD 14.6) and 6 males with a mean age of 60 years (SD 8.07), without clinical history of laryngeal pathology, tumors in the cervical region, and metabolic or degenerative disorders of the neuromuscular system. This study was performed according to Chilean law, which allows the use of cadavers for research in universities.

The vocal muscle was obtained by an assisted dissection stereomicroscope (10X) from the right hemilarynx blocks removed during the necropsy and immediately fixed in modified Millonig formalin by Carlson ( $\mathrm{pH} 7.2$ and 0.1 $\mathrm{M}$ in buffer phosphate) (Sheehan \& Hrapchack, 1980).

Each block of vocal muscle was included in Paraplast Plus (Sigma®) and serially sectioned at a thickness of $7 \mathrm{~mm}$ with transverse orientation.

Analysis. Antimyosin skeletal slow BA-F8 (DSM, Germany) for type I fibers, and antimyosin skeletal fast $\mathrm{HC}$ and MY32 (Sigma) monoclonal antibodies for types IIA, IIB, IIX, and neonatal fibers were used. The sections were analyzed with an Olympus BX40 microscope (Olympus Corporation, Melville, NY) and with the image analysis software I-Cube (Image Pro Plus, Silver Spring, MD), which identified the minimum diameter limits for different types of fibers; the statistical analysis was performed by one-way ANOVA with $\mathrm{p}<0.05$.

We performed a direct comparison of the sections, evaluating the fiber type composition in each sample by differential staining of the fibers. The quantity of each type of fiber was calculated by observing the micrographs in an area of $1 \mathrm{~mm}^{2}$.

The sample was classified by sex and age group (of 36-59 and 60-79 years), and to compare the nonparametric statistics, Mann-Whitney and Kruskal-Wallis tests with Bonferroni post test, at $\mathrm{p}<0.05$, were used.

\section{RESULTS}

The fibers in the vocal muscle histology were of heterogeneous types, with a clear predominance of brown fibers (type I). Figure 1 shows the distribution of the muscle fibers that make up the human voice.

In the analyzed samples, a positive reaction to fiber Types I, IIA, and IIX was found. Type II fibers accounted for $51.99 \%$, and Type I fibers for $48.01 \%$; this difference was significant $(\mathrm{p}<0.05)$. The frequency of the fiber subtypes IIA and IIX in the vocal muscle showed no statistically significant difference between them $(\mathrm{p}>0.05)$.

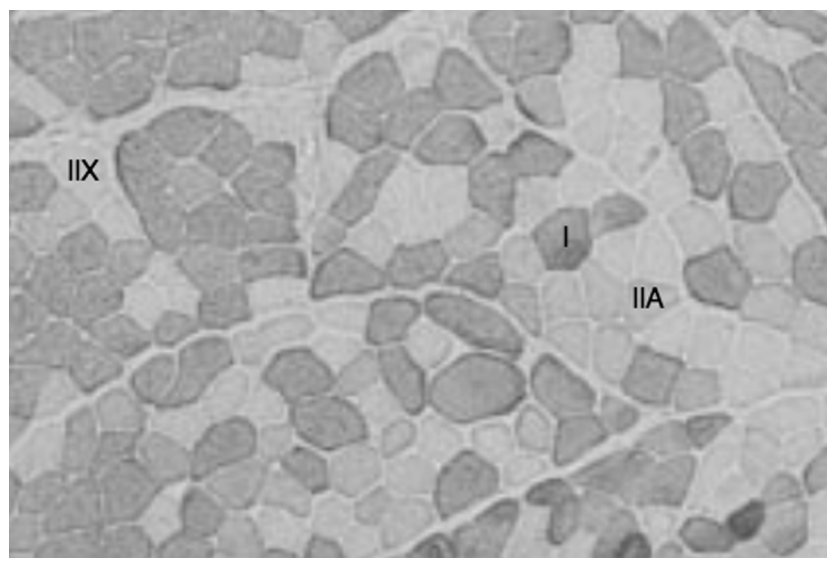

Fig. 1. Cross section microphotography of vocal muscle of a man (63 years old), reacted with antimyosin skeletal slow and fast antibodies, 400x.

The breakdown of the percentage distribution of fiber types is shown in Table I. There were no significant differences in the distribution of fibers in the vocal muscle between men and women ( $\mathrm{p}>0.05)$.

There were no significant differences between age groups with regard to the distribution of fibers. Table II shows the distribution of fiber types by age group.

The results of the morphometric analysis of the fibers that constitute the vocal muscle are presented in Table III. The differences in the major and minor diameters of the different fiber types were not significant ( $p>0.05)$.

Table I. Distribution of different types of muscle fibers in the human vocal muscle.

\begin{tabular}{lccc}
\hline & \multicolumn{3}{c}{ Relative percentage of fiber types in $1 \mathrm{~mm}^{2}$} \\
\hline \multirow{3}{*}{ Women } & Type I & Type IIA & Type IIX \\
Men & $47.0 \%$ & $24.7 \%$ & $28.2 \%$ \\
Total & $48.6 \%$ & $25.5 \%$ & $25.7 \%$ \\
\hline
\end{tabular}

*Kruskal-Wallis test with Bonferroni post test $\mathrm{p}>0.05$. 
Table II. Distribution of different types that constitute the vocal muscle of each age group.

\begin{tabular}{lcccccc}
\hline & \multicolumn{3}{c}{$36-59$ years } & \multicolumn{3}{c}{$60-79$ years } \\
\cline { 2 - 7 } Mean & Type I & Type IIA & Type IIX & Type I & Type IIA & Type IIX \\
\cline { 2 - 6 } SD & 121.2 & 65.8 & 71 & 128.2 & 65.2 & 68 \\
Percentage & 5.8 & 5.9 & 7.7 & 5.4 & 10.4 & 1.8 \\
\hline SD - Standar & $46.8 \% *$ & $25.5 \% *$ & $27.5 \% *$ & $49.0 \% *$ & $24.9 \% *$ & $26.0 \% *$ \\
\hline
\end{tabular}

Table III. Results of the morphometric analysis of the vocal muscle fibers. The unit dimensions are in $\mu \mathrm{m}$.

\begin{tabular}{lcccccc}
\hline & \multicolumn{2}{c}{ Type I* } & \multicolumn{2}{c}{ Type IIA* } & \multicolumn{2}{c}{ Type IIX* } \\
\cline { 2 - 7 } Mean $(\mu \mathrm{m})$ & Major diameter & Minor diameter & Major diameter & Minor diameter & Major diameter & Minor diameter \\
SD & 37.5 & 21.5 & 36.2 & 20.6 & 37.8 & 21.1 \\
\hline
\end{tabular}

$\mathrm{SD}=$ Standar desviation. *Mann-Whitney test with Bonferroni post test $\mathrm{p}>0.05$.

\section{DISCUSSION}

In this research, the human vocal muscle presented a mixed constitution, with a slight predominance of Type II fibers $(51.99 \%)$ of the subtypes IIA and IIX over Type I fibers $(48.01 \%)$. These results are consistent with those described by several authors (Hoh; Shiotani et al., 1999a; Shiotani et al., 1999b) who also argues that the distribution of vocal muscle fibers varies in the different portions thereof. The presence of a higher percentage of Type II fibers could be explained by the high specialization of the vocal muscle and the high speed of contraction of laryngeal muscles and reflexes, which are needed for certain functions in mammals, such as the protection of the airways, breathing, and phonation (Han et al., 1999).

The constituent changes in the vocal muscle have been poorly studied; in this regard, some authors suggest that age would play an important role in reducing type II fibers and producing a slight increase in type I fibers, which are associated with decreased vocal efficiency. Our data suggest this phenomenon and, although the difference we found was not statistically significant, may be relevant from a clinical standpoint. On the other hand, the evidence suggests that neurodegenerative diseases and neurological disorders may induce changes in the vocal muscle composition, indicating the role of neural regulation in the fiber types that constitute the intrinsic muscles of the larynx (Hoh; Rodeño et al., 1993).

The analysis conducted in this research was done in the middle third of the muscle, thereby limiting inferences regarding this particular portion, for which interest would be addressing the other segments that provide background information on the existence or no different areas and relate to the clinical manifestations of disorders of phonation.

In conclusion the human vocal muscle presented a heterogeneous formation with a predominance of fast type muscle fibers, but a high percentage of slow type fiber and no differences attributable to sex and age.

The knowledge of the morphology of the normal constituents of the vocal muscle opens new horizons regarding the study of the effect of aging, diseases, noxious agents, and therapeutic interventions might have on its composition, allowing the adoption of preventive strategies and the evaluation of the effectiveness of treatment strategies for vocal disorders.

LÓPEZ, M. J.; ZÁRATE, M.; CANTÍN, M.; ZAVANDO, D. \& SUAZO, G. I. Perfil inmunohistoquímico de los tipos de fibras en el músculo vocal humano. Int. J. Morphol., 29(4):1158-1161, 2011.

RESUMEN: El músculo vocal es un músculo estriado con importantes funciones en la emisión del sonido laringeo y fisiología de la voz. Por ello el conocimiento de su constitución sirve de base para la prevención y manejo de los trastornos vocales. Se realizó un estudio morfométrico e inmunohistoquímico de músculo vocal humano. Se utilizaron 10 muestras del tercio medio del músculo vocal obtenidas de necropsias, 6 de individuos de sexo masculino y 4 femenino, con edades de entre 36 y 71 años. Las muestras fueron analizadas con anticuerpos monoclonales antimyosin skeletal slow BA-F8 para fibras tipo I y antimyosin 
skeletal fast HC y MY-32 para fibras tipo IIA, IIB, IIX y neonatal. Se determinó la distribución de los distintos tipos de fibras musculares y sus características morfométricas, evaluándose las diferencias por sexo y grupo etáreo. El músculo vocal humano presentó una constitución heterogénea con predominio de fibras tipo II con un $51,99 \%$, mientras que las tipo I alcanzaron el $48,01 \%$, estas diferencias resultaron significativas $(\mathrm{p}<0,05)$. Al comparar los subtipos de fibras IIA y IIX, se observa un leve predominio de las fibras IIX, aunque no significativo estadísticamente $(\mathrm{p}>0,05)$. No se encontraron diferencias en cuanto a los diámetros mayor y menor de las fibras ni en la constitución del músculo por sexo o grupo etáreo. Se concluye que en el músculo vocal humano predominan las fibras musculares rápidas tipo II.

PALABRAS CLAVE: Voz; Plieges vocales; Músculos laringeos; Miosina tipo I; Miosina tipo II; Inmunohistoquímica.

\section{REFERENCES}

Di Fiore, M. Atlas de Histología Normal. $7^{\text {th }}$ ed. Buenos Aires, El Ateneo, 2001.

Dubowitz, V.; Sewry, C. \& Fitzsimons, R. Muscle Biopsy: A practical approach. London, Baillière Tindall, 1985.

Guida, H. L. \& Zorzetto, N. L. Morphometric and histochemical study of the human vocal muscle. Ann. Otol. Rhinol. Laryngol., 109(1):67-71, 2000.

Han, Y.; Wang, J.; Fischman, D. A.; Biller, H. F. \& Sanders, I. Slow tonic muscle fibers in the thyroarytenoid muscles of human vocal folds; a possible specialization for speech. Anat. Rec., 256(2):146-57, 1999.

Hebling, A.; Esquisatto, M. A. M. \& Castro, L. H. Estudio Histoquímico de la Enzima NADH-TR en Músculo Frontal de Conejos Norfolk (Oryctolagus cuniculus). Int. J. Morphol., 24(2):151-4, 2005.

Hoh, J. F. Laryngeal muscle fibre types. Acta Physiol. Scand., 183(2):133-49, 2005.

Latarjet, M. \& Ruiz Liard, A. Anatomía Humana. $3^{\text {rd }}$ ed. Madrid, Médica Panamericana, 1997. Vol 2.

López Chicharro, J. Fisiología del ejercicio. $3^{\text {rd }}$ ed. Madrid, Ed. Panamericana, 2006.

Rhee, H. S.; Lucas, C. A. \& Hoh, J. F. Fiber types in rat laryngeal muscles and their transformations after denervation and reinnervation. J. Histochem. Cytochem., 52(5):581-90, 2004.

Rhee, H. S.; Steel, C. M.; Derksen, F. J.; Robinson, N. E. \& Hoh, J. F. Immunohistochemical analysis of laryngeal muscles in normal horses and horses with subclinical recurrent laryngeal neuropathy. J. Histochem. Cytochem., 57(8):787-800, 2009.
Rodeño, M. T.; Sánchez-Fernández, J. M. \& Rivera-Pomar, J. M. Histochemical and morphometrical ageing changes in human vocal cord muscles. Acta Otolaryngol., 113(3):445-9, 1993.

Sheehan, D. C. \& Hrapchack, B. B. Theory and Practice of Histotechnology. $2^{\text {nd }}$ ed. St. Louis, Mosby, 1980.

Shiotani, A.; Westra, W. H. \& Flint, P. W. Myosin heavy chain composition in human laryngeal muscles. Laryngoscope, 109(9):1521-4, 1999a.

Shiotani, A.; Jones, R. M. \& Flint, P. W. Postnatal development of myosin heavy chain isoforms in rat laryngeal muscles. Ann. Otol. Rhinol. Laryngol., 108(5):509-15, 1999b.

Wu, Y. Z.; Baker, M. J.; Crumley, R. L. \& Caiozzo, V. J. Singlefiber myosin heavy-chain isoform composition of rodent laryngeal muscle: modulation by thyroid hormone. Arch Otolaryngol. Head Neck Surg., 126(7):874-80, 2000a.

Wu, Y. Z.; Crumley, R. L. \& Caiozzo, V. J. Are hybrid fibers a common motif of canine laryngeal muscles? Singlefiber analyses of myosin heavy-chain isoform composition. Arch. Otolaryngol. Head Neck Surg., 126(7):865-73, 2000b.

Correspondence to:

Prof. Dr. Iván Suazo Galdames

Morfología

Avenida Lircay s/n oficina $\mathrm{N}^{\circ} 104$

Universidad de Talca

CHILE

Email: isuazo@utalca.cl

Received: 27-07-2011

Accepted: 07-09-2011 